\title{
AN APPROACH TO THE DIRECT MEASUREMENT OF COMMUNITY MEAN INFORMATION FIELDS
}

\author{
By Duane F. Marble and John D. Nystuen
}

\author{
The authors are, respectively, Associate Professor of Geography \\ at Northwestern University and Assistant Professor of Geography \\ at the University of Michigan. The work was carried out while \\ Professor Marble was atiached to the faculty of the Department of \\ Regional Science of the University of Pennsylvania. The authors \\ would like to express their appreciation to Professors Waldo Tobler \\ and Forrest Pitts for their assistance and comments, and to the \\ National Science Foundation which supported the research through \\ a grant to the Regional Science Research Institute.
}

THE LAST DECADE has seen an increasing growth of interest in studies of the spatial structure of the diffusion process. The pioneering work of Professor Torsten Hägerstrand of the Royal University of Lund (Sweden) provided much of the original stimulus for research in this area, and his continuing research on Monte Carlo models for the stimulation of the diffusion process has provided the basic framework within which most subsequent studies have operated. ${ }^{1}$ Among the most basic assumptions of Hägerstrand's simulation models are those which pertain to the manner in which information about the innovation is transferred from one person to another within the spatial system. The present study represents an attempt to perform some preliminary checks on the validity of the surrogate measurement techniques which have been used by Hägerstrand, and others, to generate the simulation inputs dealing with information transfer in the system.

Basically, Hägerstrand assumes that information about the innovation is spread only by telling (oral communication) at pairwise meetings of persons, and that the probability of being paired with a carrier of information about the innovation depends upon the geographical distance between the teller and the receiver in a way which may be determined by empirical estimate. ${ }^{2}$ The first assumption, relating to the means by which the information transfer takes place, is well in line with the results of studies which have been undertaken by research workers in the fields of rural sociology and mass communications. The importance of person-to-person contacts has been pointed out in numerous studies which have investigated the factors influencing the adoption of innovations from a non-spatial standpoint. ${ }^{3}$ One author (Rodgers) feels that the impersonal information sources (e.g., mass media) are most important at the awareness stage, and that personal sources are more important at the evaluation stage in the adoption process ${ }^{4}$. Katz has also stressed the growing realization, on the part of persons studying the role of mass media in our society, that person-to-person contacts retain a high level of significance in the transfer of information even when the society involved may be nearly saturated

PAPERS AND PROCEedings OF the REgIONAL SCIENCE ASSOCIATION, VOLUME ELEVEN, 1963 
by the various mass media."

In so far as Hägerstrand's simulation models are concerned, the second assumption (dealing with the relationship of geographical distance of frequency of contact) is operationally defined via the concept of the Mean Information Field (MIF). The MIF is designed to express the average spatial extent of an individual's short-term (i.e., non-migratory) contacts. The major difficulty which arises in the operational specification of the MIF is that no body of information is available which treats the problem of the spatial structure of non-migratory household contacts in any depth. ${ }^{6}$ While it is generally agreed that the bulk of such contacts tend to occur at quite short distances, researchers who need to develop a MIF for a specific research situation have been forced to fall back upon one of several classes of information which appear to provide likely surrogates for the measurement of direct personal contacts in space. Hägerstrand, for instance, based the development of his MIF's largely upon local migration data. This type of information is quite readily available in Sweden and he concluded that it would provide a valid surrogate for the desired personal contact field since several recent studies of migration fields have stressed the close relationship which exists between the spatial extent of the migration field and the web of social contacts. ${ }^{7}$ Other researchers have made use of MIF's derived from marriage distances (that is, the distance between the residences of the bride and groom prior to their marriage) since information on this surrogate is more readily available in some areas, and its links with the pattern of social contacts in space are perhaps somewhat more appealing on an intuitive basis. ${ }^{8}$

Whichever surrogate is utilized, the MIF is generated in a rather straightforward fashion. From mapped raw data on, say, local migration movements, a chart is constructed showing the point of origin (which is always at the center of the coordinate system) and the point of termination of each movement. A series of rings is then drawn about the center of the coordinate system and the number of points of termination in each ring is tabulated. This produces a body of directionally smoothed information of the type displayed in Table I. A Pareto curve of the general form $Y=a D^{-b}$ is then fitted to the tabulated information by least-squares techniques. For the information presented in Table I, Hägerstrand notes that the curve has the form $Y=6.26 D^{-1.585}$, where $Y$ is the expected number of migrants per square kilometer and $D$ is the distance from the point of origin in kilometers. A twentyfive cell grid (with each cell measuring $5 \times 5$ kilometers) is then constructed and the estimating equation is used to provide point estimates of the expected number of migrants in each of the twenty-four exterior cells. Because of the Pareto curves' rather strong tendency toward overestimation at short distances, actual instead of expected numbers of migrants are entered in the center cell. (See Table II.) When these figures are converted to probabilities, by dividing each cell entry by the sum of all cell entries, the expected migration field becomes the mean information field for the diffusion model (see Table III). The manner in which this information is subsequently utilized in the simulation model has been described in some detail by Hägerstrand and others and 
TABLE I. Observed Local Migration in the Asby Area.

\begin{tabular}{c|c|c|c}
\hline $\begin{array}{c}\text { Distance in } \\
\text { Kilometers }\end{array}$ & $\begin{array}{c}\text { Number of Migrating } \\
\text { Households }\end{array}$ & $\begin{array}{c}\text { Ring Area in Sq. } \\
\text { Kilometers }\end{array}$ & $\begin{array}{c}\text { Number of Migrating } \\
\text { Households Per Km. }\end{array}$ \\
\hline $0.0-0.5$ & 9 & 0.79 & 11.39 \\
$0.5-1.5$ & 45 & 6.28 & 7.17 \\
$1.5-2.5$ & 45 & 12.57 & 3.58 \\
$2.5-3.5$ & 26 & 18.85 & 1.38 \\
$3.5-4.5$ & 28 & 25.14 & 1.11 \\
$4.5-5.5$ & 25 & 31.42 & 0.80 \\
$5.5-6.5$ & 20 & 37.70 & 0.53 \\
$6.5-7.5$ & 23 & 43.99 & 0.52 \\
$7.5-8.5$ & 18 & 50.27 & 0.36 \\
$8.5-9.5$ & 10 & 56.56 & 0.18 \\
$9.5-10.5$ & 17 & 62.82 & 0.27 \\
$10.5-11.5$ & 7 & 69.12 & 0.10 \\
$11.5-12.5$ & 11 & 75.41 & 0.15 \\
$12.5-13.5$ & 6 & 81.69 & 0.07 \\
$13.5-14.5$ & 2 & 87.98 & 0.02 \\
$14.5-15.5$ & 5 & 94.26 & 0.05 \\
\hline
\end{tabular}

Source: Adapted from Hägerstrand (1953), page 190.

TABLE II. Expected Migration Grid for the Asby Area.

\begin{tabular}{|c|c|c|c|c|}
\hline 2.38 & 3.48 & 4.17 & 3.48 & 2.38 \\
\hline 3.48 & 7.48 & 13.57 & 7.48 & 3.48 \\
\hline 4.17 & 13.57 & 110.00 & 13.57 & 4.17 \\
\hline 3.48 & 7.48 & 13.57 & 7.48 & 3.48 \\
\hline 2.38 & & & & \\
\hline & & & & \\
\hline
\end{tabular}

Source: Hägerstrand (1953), page 246. Cells are $5 \times 5 \mathrm{~km}$.

need not concern us here. ${ }^{9}$

The question might well be raised at this point; just what are the charac- 
TABLE III. Mean Information Field for the Asby Area.

\begin{tabular}{|l|l|l|l|l|}
\hline .0096 & .0140 & .0168 & .0140 & .0096 \\
\hline .0140 & .0301 & .0547 & .0301 & .0140 \\
\hline .0168 & .0547 & .4431 & .0547 & .0168 \\
\hline .0140 & .0301 & .0547 & .0301 & .0140 \\
\hline .0096 & .0140 & .0168 & .0140 & .0096 \\
\hline
\end{tabular}

Source: Hägerstrand (1953), page 247.

Note: The entries in each cell denote the probability of a receiver in that cell coming in contact with a carrier of information who is assumed to originate in the center cell. Cells are $5 \times 5 \mathrm{~km}$.

teristics of an actual personal contact field and how well do the various surrogates represent it? The generation of an empirically based personal contact field would require the collection of detailed information on all movements and contacts of a fairly large group of persons, perhaps over a period of several days or even weeks. The information on interzonal transfers collected by the major urban transportation studies appears at first glance to provide a potential body of data for such investigations, but a closer examination reveals certain differences in definition of trips, etc., which would effectively prevent the use of this information. However, in 1949 a private research group (the Traffic Audit Bureau) undertook a study of the movement patterns of a sample of households in and around Cedar Rapids, lowa. All members of the sample households who were ten years of age and older were paid to keep travel diaries which recorded routes, times, location of stops, etc., for all trips made by all modes during the thirty day study period. ${ }^{10}$ While certain biases appear to exist in this body of data (e.g., visits to gas stations and certain other specialized retail facilities appear to be underreported) it seems to be the only existing body of information which could be used to develop a personal contact field.

The Cedar Rapids travel information is currently being prepared for analysis by the staff of the Household Travel Behavior Study, a research operation conducted by the Regional Science Research Institute under the terms of a grant from the National Science Foundation. Card deck five of the 
HTBS provides, for each trip in the sample, the location of the residence (the point of origin of the trip) and the purpose and location of each stop which was made. ${ }^{11}$ The nature of the locational coding on these cards is such that it is fairly easy to calculate the distance and direction of each stop in relation to the location of the residence. A computer program has been developed for the HTBS which accepts deck five cards as input and produces tabulations of the number of contacts which occur in each cell of a system of $15^{\circ}$ sectors and 0.1 mile rings centered on the residence location. ${ }^{12}$ When deck five is completely punched, it will provide a record of the location of all visits made within the thirty day period by the members of some 250 households (about 4/5ths of which are located within the Cedar RapidsMarion urbanized area). At the present time about one-fourth of the urban households are completely processed; a number which appears to be sufficient for the production of some provisional figures. Table IV presents the distancecontact frequency relationships derived from 5,128 visits made by the members of forty-nine of the sample households during the 30 day study period. Treating this information in the manner proposed by Hägerstrand produces a summary expression of the form $Y=197.7 D^{-3.035}$ where $Y$ is the number of contacts per square mile and $D$ is the distance from the residence in miles. Hägerstrand's

TABLE IY. Observed Personal Contacts in Cedar Raplds.

\begin{tabular}{c|r|c}
\hline Ring & Number of Contacts & Contacts per Sq. Mile \\
\hline $0.00-0.50$ & 1661 & 2115.92 \\
$0.50-1.00$ & 770 & 326.69 \\
$1.00-1.50$ & 1082 & 275.53 \\
$1.50-2.00$ & 442 & 80.41 \\
$2.00-2.50$ & 584 & 82.72 \\
$2.50-3.00$ & 301 & 34.88 \\
$3.00-3.50$ & 73 & 7.15 \\
$3.50-4.00$ & 80 & 6.79 \\
$4.00-4.50$ & 47 & 3.52 \\
$4.50-5.00$ & 4 & 0.268 \\
$5.00-5.50$ & 4 & 0.242 \\
$5.50-6.00$ & 18 & 0.996 \\
$6.00-6.50$ & 9 & 0.458 \\
$6.50-7.00$ & 8 & 0.377 \\
$7.00-7.50$ & 4 & 0.176 \\
$7.50-8.00$ & 0 & 0.000 \\
$8.00-8.50$ & 35 & 1.350 \\
$8.50-9.00$ & 2 & 0.069 \\
$9.00-9.50$ & 0 & 0.000 \\
\hline & & \\
\hline
\end{tabular}

Note: The mean distance of the sample households from the Cedar Rapids CBD was 1.35 miles. 
PAPERS AND PROCEedings OF tHE REGIONAL SCIENCE ASSOCIATION

TABle V. Expected Personal Contact Grid for Cedar Rapids.

\begin{tabular}{|l|l|l|l|l|}
\hline \hline 2.62 & 5.30 & 7.48 & 5.30 & 2.60 \\
\hline 5.30 & 21.42 & 60.98 & 21.42 & 5.30 \\
\hline 7.48 & 60.98 & 3677 & 60.98 & 7.48 \\
\hline 5.30 & 51.42 & 60.98 & 21.42 & 5.30 \\
\hline 2.62 & & & & \\
\hline & & & & \\
\hline
\end{tabular}

Note: Cells are $5 \times 5 \mathrm{~km}$.

TABLE VI. Mean Information Field for Cedar Rapids.

\begin{tabular}{|l|l|l|l|l|}
\hline .0006 & .0013 & .0018 & .0013 & .0006 \\
\hline .0013 & .0052 & .0149 & .0052 & .0013 \\
\hline .0018 & .0149 & .8990 & .0149 & .0018 \\
\hline .0013 & .0052 & .0149 & .0052 & .0013 \\
\hline .0006 & .0013 & .0018 & .0013 & .0006 \\
\hline
\end{tabular}

Note: Cells are $5 \times 5 \mathrm{~km}$.

reported figure for Asby was, as mentioned previously $Y=6.26 D^{-1.585}$. The expected contact grid and the mean information field derived from the Cedar Rapids data are displayed in Tables V and VI respectively. An examination 
MARBLE AND NYSTUEN: MEASUREMENT OF COMMUNITY MEAN INFORMATION FIELDS

TABLE VII. Mean Information Field for Kagawa Prefecture (Japan).

\begin{tabular}{|l|l|l|l|l|}
\hline .0103 & .0150 & .0181 & .0150 & .0103 \\
\hline .0150 & .0279 & .0557 & .0279 & .0150 \\
\hline .0181 & .0557 & .4319 & .0557 & .0181 \\
\hline .0150 & .0279 & .0557 & .0279 & .0150 \\
\hline .0103 & .0150 & .0181 & .0150 & .0130 \\
\hline
\end{tabular}

Note: This field is derived from marriage distance information and was communicated to the authors by Professor Forrest R. Pitts of the University of Oregon. Cells are $5 \times 5 \mathrm{~km}$.

of the Cedar Rapids and Asby results (as well as those reported by Pitts in Japan-see Table VII) clearly reveals that the majority of personal contacts do indeed occur at very short distances, but that apparently the MIF derived from the Cedar Rapids contact data exhibits a much faster rate of decay with increasing distance.

It should be clearly recognized however that both the Asby and Kagawa MIF's were derived from surrogate measures and in areas which are rural and semi-rural in nature. Cedar Rapids, on the other hand, is an example of a medium-sized American city, and most of the observed contacts took place well within the limits of the built-up area. One possible explanation for the differences in decay rates (other explanations might be based upon supposed differences in transport technology, cultural bias, etc.) may be found in a series of central place studies which were recently conducted in this country by Dr. Brian J.L. Berry of the University of Chicago. ${ }^{14}$ These studies have clearly demonstrated that a strong tendency toward the diminution of what we might call "mean contact distance" develops as the gross population density of the area increases. Following this notion through, we might then expect to find that the mean information field in Cedar Rapids (a relatively high density area via-a-vis Asby and Kagawa) is steeper than in the two rural areas. This indeed is what was observed, but the situation would be still further clarified if some firm notion were available of the type of mean information field that would be generated in an urban area through the use of one of the various surrogate measures. Ideally, a MIF for Cedar Rpaids could be obtained 
through the use of any one of the surrogate measures, but on a practical basis it appears that only marriage distances will be available without the expenditure of excessive amounts of time and resources. It is indeed frustrating that a ruling of the Iowa Division of Vital Statistics has prevented our making use of this material at the present time. ${ }^{15}$ There are a number of sociological studies of marriage distances in several American cities, but all of those examined to date have reported their distances in terms of city blocks of unknown lengths. ${ }^{16}$ This, of course, effectively eliminates them as a possible source of comparative data.

However, Stouffer in his now historic article on intervening opportunities does present some detailed local migration data for twelve "white" census tracts in metropolitan Cleveland, Ohio, for the years $1933-1936 .{ }^{17}$ (See Table VIII.) Reducing these observations to the standard format set forth by Hägerstrand produces a summary expression of the form $Y=458.7 D^{-2.49}$, where $Y$ is the expected number of migrating households per square mile and $D$ is the dis. tance in miles from the original residence location. The expected migration field and the associated mean information field are displayed in Tables IX and X.

The Cleveland urban MIF represents a much closer approach to the observed direct contact field of Cedar Rapids than either of the two rural fields detailed earlier in this paper. It would, however, be a mistake to conclude at this time that the surrogate measures which have been used elsewhere do in-

TABLE VIII. Observed Local Migration in the Cleveland Area (Circa 1935).

\begin{tabular}{|c|c|c|}
\hline $\begin{array}{c}\text { Ring Center Distance } \\
\text { In Miles }\end{array}$ & $\begin{array}{c}\text { Number of Migrating } \\
\text { Households }\end{array}$ & $\begin{array}{c}\text { Number of Migrating } \\
\text { Households per Sq. Mile }\end{array}$ \\
\hline 0.29 & 5,585 & 5,475 \\
0.86 & 2,471 & 808 \\
1.43 & 1,313 & 263 \\
2.00 & 737 & 104 \\
2.57 & 431 & 47 \\
3.14 & 320 & 29 \\
3.71 & 217 & 16 \\
4.28 & 178 & 12 \\
4.85 & 172 & 10 \\
5.42 & 125 & 6.5 \\
5.99 & 137 & 6.4 \\
6.56 & 106 & 4.5 \\
7.13 & 85 & 3.3 \\
7.70 & 102 & 3.8 \\
8.27 & 102 & 3.5 \\
8.84 & 57 & 1.8 \\
9.41 & 30 & 0.9 \\
9.98 & 39 & 1.1 \\
\hline
\end{tabular}

Source: Adapted from Stouffer (1940). 
deed provide a valid measure of the true spatial structure of the mean information field. While it has been shown that the Cedar Rapids travel data are quite adequate for the direct measurement of that community's mean information

TABLE IX. Expected Migration Grid for the Cleveland Area.

\begin{tabular}{|c|c|c|c|c|}
\hline 19.98 & 35.72 & 47.28 & 35.72 & 19.98 \\
\hline 35.72 & 111.88 & 263.70 & 111.88 & 35.72 \\
\hline 47.28 & 263.70 & 9440 & 263.70 & 47.28 \\
\hline 35.72 & 111.88 & 263.70 & 111.88 & 35.72 \\
\hline 19.98 & 35.72 & & & \\
\hline & & & & \\
\hline
\end{tabular}

Note: Cells are $5 \times 5 \mathrm{~km}$.

TABLE X. Moan Information Fleld for the Cleveland Area.

\begin{tabular}{|l|l|l|l|l|}
\hline \hline .0017 & .0031 & .0041 & .0031 & .0017 \\
\hline .0031 & .0097 & .0229 & .0097 & .0031 \\
\hline .0041 & .0229 & .8211 & .0229 & .0041 \\
\hline .0031 & .0097 & .0229 & .0097 & .0031 \\
\hline .0017 & & & & .0017 \\
\hline
\end{tabular}

Note: Cells are $5 \times 5 \mathrm{~km}$. 
field, the comparative fields based upon surrogate measures for the same area and time period are currently lacking. The Cleveland data, as well as the results of Berry's studies on the range of a good, do provide some definite encouragement, but a final decision on the validity of the surrogate measures must wait upon a more detailed and comprehensive examination. Difficulties in obtaining access to certain public records has prevented the inclusion of MIF's based upon surrogate measures at this time, but it is believed that this obstacle will be eliminated in the near future.

One other interesting feature of the personal contact field was revealed when the directional tabulations were examined. Let us imagine a line drawn from each household to a point in the center of the Cedar Rapids CBD. This line will serve as a basic reference, and in the coordinate system it will be $0^{\circ}$. Now if a sector is defined with its origin at the residence location and its two bounds the $330^{\circ}$ and $30^{\circ}$ lines (with respect to our base line) some interesting deviations appear in the tabulations. The smaller sector, which might be called "CBD oriented" accounts for nearly $60 \%$ of the contacts of the average household, while the remaining $40 \%$ of the contacts are distributed unevenly throughout the remaining large sector. Very little attention has been given to the examination of the directional structure of urban travel, but the preliminary results reported upon here would certainly seem to indicate that more attention should be given to this topic. ${ }^{18}$ The computer simulation models of diffusion utilized by Hägerstrand and Pitts do incorporate some directional distortions, but these are not built into the MIF and are held to be the result of physical barriers which act in such a manner as to hinder communication. One of the first steps in the production of a MIF from one of the various surrogate measures involves the directional smoothing of the data. If the surrogate contacts are found to display as large a degree of directional bias as the direct contact field examined here, it would appear that some major adjustments will have to be made in the internal structure of the current simulation models. With the cooperation of Professor Pitts of the University of Oregon, the Kagawa marriage distance data are currently being analyzed for the presence of directional bias and it is hoped that a report on the results of this investigation will be available in the near future.

\section{REFERENCES}

[1] Hägerstrand, Torsten. Innovationsförloppet ur Koroloqisk Synpunkt, Meddelanden fran Lunds Universitets Geografiska Institution, Avhandlingar XXV. Lund, Sweden: Gleerupska Univ.-Bokhandeln, 1953.

[2] Hägerstrand, Torsten. "On Monte Carlo Simulation of Diffusion," in W.L. Garrison (ed.), Quantitative Geography. New York: Atherton Press, forthcoming.

[3] Lionberger, Herbert F. Adoption of New Ideas and Practices. Ames: Iowa State University Press, 1960.

Rogers, Everett M. Diffusion of Innovations. New York: The Free Press of Glencoe, 1962.

[4] Rogers, Everett M. op. cit.

[5] Katz, Elihu. "Communications Research and the Image of Society: Convergence of Two Traditions," American Journal of Sociology, 65: 435-440 (1960). 
[6] A small amount of information on this topic is available, see sections III, IV, and V in W.L. Garrison, B.J.L. Berry, D.F. Marble, J.D. Nystuen, and R.L. Morrill, Studies of Highway Development and Geographic. Change. Seattle: University of Washington Press, 1959.

[7] Hägerstrand, Torsten. "Migration and Area: Survey of a Sample of Swedish Migration Fields and Hypothetical Considerations on Their Genesis," in Hannerberg, Hägerstrand, and Odeving (eds.), Migration in Sweden. Lund University Studies in Geography, Series B (Human Geography) No. 13. Lund, Sweden: C.W.K. Gleerup, 1957.

[8] Personal communication from Professor Forrest R. Pitts of the Department of Geography of the University of Oregon.

[9] Hägerstrand, Torsten. "On Monte Carlo Simulation...," op. cit.

[10] Details of the study design, sampling proceedures, etc., are reported in William L. Garrison, et. al, op. cit.

[11] Regional Science Research Institute. Card Format and Coding. Working Paper No. 1 of the Household Travel Behavior Study. Philadelphia 1962. (mimeo)

[12] Dr. Waldo Tobler of the Department of Geography of the University of Michigan provided valuable assistance in the original formulation of the analysis program.

[13] Personal communication from Professor Forrest R. Pitts.

[14] Berry, Brian J.L. and Harold Mayer. Comparative Studies of Central Place Systems. Final report of project NONR 2121-18 (NR 389-129), Department of Geography, University of Chicago, February, 1962.

[15] An exception to this ruling has recently been obtained, and a MIF based on marriage distances is currently being generated.

[16] A number of these studies are summarized in Gunnar Boalt and Carl-Gunnar Janson's "Distance and Social Relations," Acta Sociologica, 2:73-97 (1957).

[17] Stouffer, Samuel A. "Intervening Opportunities: A Theory Relating Mobility and Distance," American Sociological Review, 5:845-867 (December 1940).

[18] The only study on this topic which has come to our attention is Gordon F. Sutton's "Travel Patterns in an Urban Community," unpublished Ph. D. dissertation, University of Michigan, 1959. 